\title{
A cilostazol diabeteses betegekben is javítja az életminőséget és az alsó végtagi funkcionális kapacitást
}

\author{
Farkas Katalin dr. ${ }^{1,3}$ - Kolossváry Endre dr. ${ }^{1}$ - Járai Zoltán dr. ${ }^{2,3}$ \\ ${ }^{1}$ Szent Imre Egyetemi Oktatókórház, Angiológia, Budapest \\ ${ }^{2}$ Szent Imre Egyetemi Oktatókórház, Kardiológia, Budapest \\ ${ }^{3}$ Semmelweis Egyetem, Angiológia Tanszéki Csoport, Budapest
}

\begin{abstract}
Bevezetés: A claudicatio intermittens jelentős negatív hatással van a betegek életminőségére. A különböző revascularisatiós eljárások és a noninvazív orvosi kezelések javíthatják a betegek járását. A cilostazol I.A ajánlással rendelkezik a claudicatio intermittens kezelésére.

Célkitüzés: Vizsgálatunk célja a 3 hónapos cilostazolkezelésnek az egészséggel kapcsolatos életminőségre és az alsó végtag funkcionális kapacitására gyakorolt hatásának értékelése a klinikai gyakorlatban, claudicatio intermittensben szenvedő diabeteses (DM) és nem diabeteses (NDM) betegek körében.

Módszer: A tanulmány multicentrikus, beavatkozással nem járó vizsgálat, amelybe 812, ambuláns kezelés alatt álló, perifériás verő́rbetegségben szenvedő beteg (Fontaine II. stádium, átlagéletkor: 67,17 év, férfi/nő: 58,25/41,75\%, 318 diabeteses) került beválasztásra, akik cilostazolkezelést kaptak (50 vagy 100 mg naponta kétszer) 3 hónapig. Az életminőséget az EQ-5D-3L-kérdőívvel, a funkcionális kapacitást a WELCH-kérdőívvel értékeltük. A fájdalommentes és maximális járástávolságnak, valamint a boka-kar indexnek a mérése megtörtént a vizsgálat indulásakor és a 3 hónapos kezelés után.

Eredmények: A vizsgálat befejezése után az EQ-5D-index javult (kiindulási érték: NDM $-0,45 \pm 0,22, \mathrm{DM}-0,48 \pm$ $0,23,3$. hónap: $-0,24 \pm 0,18,-0,27 \pm 0,19 ; p<0,0001$ ), és a WELCH-pontszám szintén szignifikánsan nőtt (kiindulási érték: NDM $20 \pm 14$, DM $18 \pm 14$; 3. hónap: $33 \pm 19,29 \pm 16$; p $<0,0001)$ mindkét betegcsoportban. Mind a fájdalommentes, mind a maximális járástávolság nőtt: NDM 59,2\% (medián: 50,0\%), 46,58 (medián: 40,51\%), és DM 42,85\% (medián: 43,33\%), 41,61\% (medián: 34,68\%) (p<0,001).

Következtetés: 3 hónapos cilostazolkezelés javította az életminőséget és az alsó végtagi funkcionális kapacitást claudicatio intermittensben szenvedő betegekben, diabetes esetén is. A WELCH-kérdő́iv hasznos eszköznek bizonyult a klinikai gyakorlatban a claudicatio kezelése során a járóképesség értékelésére.
\end{abstract}

Orv Hetil. 2020; 161(38): 1637-1645.

Kulcsszavak: claudicatio intermittens, diabetes mellitus, cilostazol, életminőség, SHERIFF-vizsgálat, WELCH-kérdőív

\section{Cilostazol improves the quality of life and lower-limb functional capacity also in diabetic patients}

Introduction: Intermittent claudication has a significant negative impact on the patients' quality of life. Revascularization procedures and noninvasive medical therapies can improve walking capacity. Cilostazol has IA recommendation for the treatment of intermittent claudication.

Aim: The aim of this study was to evaluate the effect of a three-month cilostazol treatment on the health-related quality of life and on the lower-limb functional capacity in diabetic (DM) and non-diabetic patients (NDM) with intermittent claudication in the clinical practice.

Method: The study was a multicenter, non-interventional trial; 812 patients with peripheral artery disease (Fontaine II stage, mean age: 67.17 years, male/female: $58.25 / 41.75 \%, 318$ diabetics) were enrolled, who received cilostazol ( 50 or $100 \mathrm{mg}$ twice a day) for 3 months. The quality of life was evaluated with the EQ-5D-3L questionnaire, the functional capacity with the WELCH questionnaire. Walking distances, ankle-brachial index were measured at baseline and after 3 months. 
Results: Upon conclusion of the study, the EQ-5D index improved both in non-diabetic and diabetic patients (baseline: $\mathrm{NDM}-0.45 \pm 0.22, \mathrm{DM}-0.48 \pm 0.23$, 3rd month: $-0,24 \pm 0.18,-0,27 \pm 0.19$; respectively; $\mathrm{p}<0.0001)$ and there was a significant increase in the WELCH score as well (baseline: NDM $20 \pm 14$, DM $18 \pm 14$; 3rd month: $33 \pm 19,29 \pm 16$, respectively; $\mathrm{p}<0.0001$ ). Both pain-free and maximal walking distance increased by $59.2 \%$ (median: 50.0\%), 46.58 (median: 40.51\%) in NDM and 42.85\% (median: 43.33\%), 41.61\% (median: 34.68\%) in DM patients, respectively $(\mathrm{p}<0.001)$.

Conclusions: Three months of cilostazol treatment improved the quality of life and lower-limb functional capacity in diabetic and non-diabetic claudicant patients. The WELCH questionnaire is a useful tool in clinical practice for the evaluation of intermittent claudication treatment.

Keywords: intermittent claudication, diabetes mellitus, cilostazol, quality of life, SHERIFF study, WELCH score

Farkas K, Kolossváry E, Járai Z. [Cilostazol improves the quality of life and lower-limb functional capacity also in diabetic patients]. Orv Hetil. 2020; 161(38): 1637-1645.

(Beérkezett: 2020. június 25.; elfogadva: 2020. augusztus 5.)

\section{Rövidítések}

ACC $/ \mathrm{AHA}=$ American College of Cardiology/American Heart Association; BKI = boka-kar index; $\mathrm{CI}=$ claudicatio intermittens; CIL = cilostazol; $\mathrm{DM}=$ diabeteses; EuroQol $=\mathrm{az}$ Európai Életminőség Kérdőív; EQ-5D = az egészségi állapotot értékelő kérdőív; ETT TUKEB = Egészségügyi Tudományos Tanács, Tudományos és Kutatásetikai Bizottság; EU GCP/ $\mathrm{ICH}=$ European Union, Good Clinical Practice/International Conference on Harmonisation; $\mathrm{HQL}=$ (health-related quality of life) az egészséggel összefüggő életminőség; NDM = nem diabeteses; OGYÉI = Országos Gyógyszerészeti és Élelmezésegészségügyi Intézet; $\mathrm{PAD}=($ peripheral artery disease $)$ perifériás veróérbetegség; $\mathrm{PROM}=$ (patient-reported outcome measure) beteg által közölt eredménymutató; RCT = (randomised controlled trial) randomizált kontrollált vizsgálat; SF36 = a Rand Corporation Short Form kérdőívének 36 kérdéses változata; SHERIFF = SHort-tERm cIlostazol eFFicacy; VAS = (visual analogue scale) vizuális analóg skála; VASCUQOL = Vascular Quality of Life; WELCH = Walking EstimatedLimitation Calculated by History; WIQ = Walking Impairment Questionnaire

Magyarországon, a világ más fejlett országaihoz hasonlóan, a szív- és érrendszeri betegségek képezik a vezető halálokot. A perifériás veróérbetegség (PAD) az egész szervezetet érintő, generalizált atherosclerosis egyik megjelenési formája. A PAD klinikai jelentősége az utóbbi években nőtt, mivel a betegség előfordulása az átlagpopulációban magas, és növekszik (3-20\%, a 70 évesnél idősebb népességben ennél magasabb értékek); több mint 200 millió embert érint világszerte [1-4]. A PAD egyik legfontosabb rizikótényezője a cukorbetegség, az alsó végtagi amputációk felét diabeteses betegeken végzik [5]. Az érszúküulet sokáig semmilyen panaszt nem okoz, és sok esetben csak akkor kerül felismerésre, amikor a romló vérellátás következtében a járás erősen korlátozottá válik, vagy a lábon nyugalmi fájdalom, nem gyógyuló seb, fekély vagy üszkösödés alakul ki. Epidemiológiai adatok azt igazolták, hogy a PAD nemcsak a tüneti, hanem a preklinikai, tünetmentes stádiumában is a cardiovascularis mortalitás és morbiditás fokozott kockázatával jár, a többi fó cardiovascularis kockázati tényezőtől függetlenül [6-8]. A tünetekkel járó PAD (claudicatio intermittens, CI) az idősebb férfiak és nők rokkantságának és mozgásromlásának fő oka, és jelentős negatív hatással van a betegek életminőségére [9].

Fontos kérdés, hogy miként lehet optimális módon mérni a PAD-betegek tüneteit, mivel ez irányítja az öszszes terápiás beavatkozást. Elméletileg két lehetőség áll rendelkezésre. Az első a betegek fizikai teljesítményének objektív becslése a (fájdalommentes és maximális) járástávolság mérésével. E célból széles körben ajánlott a járópadlóteszt és a 6 perces járásteszt. Több tényező azonban kihívást jelent alkalmazásuk szempontjából, például az eszköz elérhetősége, a beteg preferenciái, az időigény vagy a bizonytalanság, figyelembe véve a módszer értékét a beteg életminőségének teljes komplexitása szempontjából történő értékelésében $[10,11]$. Egy másik megközelítés a különböző kérdőívek vagy a betegek által közölt, az életminőségre, fizikai, pszichés állapotra vonatkozó eredménymutatók (PROM-ok) kidolgozása, amelyek sok területen jól tükrözik a betegek funkcionális állapotát és az egészséggel kapcsolatos életminőséget [12].

A járóképesség javítható mútéti vagy endovascularis revascularisatiós eljárásokkal, de nem minden PAD-beteg alkalmas ilyen beavatkozásra: ezeknek a betegeknek egyéb, „konzervatív” kezelésre van szükségük az alsó végtagok funkcionális kapacitásának javításához. A járóképesség javítható kontrollált tréningprogrammal, de ennek a terápiás módszernek a széles körü alkalmazását a korlátozott elérhetőség akadályozza [13]. Világszerte, így Magyarországon is, a valóság szabta lehetőségeknek megfelelően egyelőre többnyire csupán a kevésbé hatásos otthoni, elő́rással irányított fizikai tréningre van mód - ez a tény tovább növeli a gyógyszeres kezelés jelentőségét. A nemzetközi és a magyar ajánlások három, evidenciákkal is rendelkező gyógyszert emelnek ki a CI kezelésében, ezek a cilostazol (CIL), a naftidrofuril és a 
pentoxifillin. A CIL az egyetlen gyógyszer, amelynek I. osztályú (A evidenciaszintú) ajánlása van a CI kezelésére az ACC/AHA irányelvek szerint [14].

A CIL egy foszfodiészteráz-3-gátló szer, vasodilatator és vérlemezkegátló hatású, emellett előnyös, szérumtrigliceridszint-csökkentő hatása is ismert. Egy Cochranemetaanalízis szerint a CIL-kezelés előnyös hatása és biztonságossága CI-ben több tanulmány alapján bebizonyosodott (15 RCT, 3718 randomizált résztvevő adatai alapján, a járástávolságok értékelése alapján) [15]. A járóképesség kihívást jelentő fizikai mérése helyett a PROM-ok használatáról a PAD-specifikus járóképesség értékelésére kevesebb adat áll rendelkezésre [12, 16, 17]. Ez utóbbi tanulmányok az alsó végtagi funkcionális kapacitás becslésére kizárólag a WIQ-kérdőívet alkalmazták, amelyet az egészségi állapot felmérésére alkalmas SF36-, illetve az alsó végtagi verőérbetegségre specifikus VASCUQOL-kérdőív használatával egészítettek ki [16, 17]. Magyarországon a CIL-t 2014-ben törzskönyvezték. Egy, a munkacsoportunk által korábban publikált magyarországi, beavatkozással nem járó, hatás- és tolerálhatóságtanulmányban (NOCLAUD-vizsgálat) 1405, Fontaine II. stádiumú beteg vett részt. A fájdalommentes és a maximális járástávolság már 3 hónapos kezelést követően szignifikánsan javult, emellett a 6 perces járásteszt is a járástávolság szignifikáns javulását igazolta. A járástávolság javulása hasonló volt férfiakban, illetve nókben, diabeteses (DM-), illetve nem diabeteses (NDM-) betegekben [18].

A SHERIFF-tanulmány elsődleges célja a 3 hónapos CIL-kezelésnek az egészséggel összefüggő életminőségre (HQL) és az alsó végtagok funkcionális kapacitására gyakorolt hatásának értékelése volt a Fontaine II. stádiumú PAD-betegekben [19]. A WELCH-pontszám a 3 hónapos CIL-kezelést követően szignifikánsan nőtt, az eredmény szignifikáns korrelációt mutatott a mért járástávolságokkal [19].

\section{Célkitüzés}

A SHERIFF-tanulmány jelen elemzésének célja az volt, hogy összehasonlítsuk a 3 hónapos CIL-kezelésnek az egészséggel összefüggő életminőségre (HQL) és az alsó végtagok funkcionális kapacitására gyakorolt hatását Fontaine II. stádiumú DM és NDM PAD-betegekben. Másodlagos célkitűzések: a fájdalommentes és a maximális járástávolságnak, a boka-kar index (BKI) változásának, a CIL-kezelés tolerálhatóságának és biztonságosságának, valamint a betegek CIL-terápiával való elégedettségének értékelése 3 hónapos kezelést követően.

\section{Módszer}

A tanulmány 3 hónapos, multicentrikus, prospektív, obszervációs, beavatkozással nem járó, nyílt klinikai vizsgálat, mely 100 vizsgálóhelyen, szakrendelőben vagy kór- házi szakambulancián zajlott, belgyógyász, belgyógyász angiológus, diabetológus és érsebész szakorvosok által. A vizsgálatot az ETT TUKEB engedélyezte (a klinikai vizsgálat nyilvántartási száma: OGYÉI/13628-1/2018).

\section{Betegek}

2018. április és 2018. június között 812 beteget vontak be a vizsgálatba, köztük 318 volt DM. A vizsgálatba bevont összes résztvevőtól tájékoztatást követően írásos beleegyezést szereztek. A fó beválasztási kritériumok a következők voltak: 18 évesnél idősebb férfi és nőbetegek; igazolt, Fontaine II. stádiumú perifériás verőbetegség; az életmód-változtatás nem volt elegendő a claudicatiós tünetek javításához; a claudicatiós panaszok miatt a beteg gyógyszeres kezelést igényelt, vagy a korábbi gyógyszeres, illetve egyéb terápia hatástalansága miatt a kezelés módosítása vált szükségessé. Az előrehaladott (Fontaine III. és IV. stádiumú) PAD-betegek, valamint a korábban CIL-kezelésben részesülők kizárásra kerültek. A betegek a bevonás után a kezelőorvos döntése alapján a napi rutingyakorlatnak megfelelően elkezdték a CILkezelést, naponta kétszer alkalmazott $50 \mathrm{mg}$ vagy 100 mg CIL-adaggal.

\section{A betegek értékelése}

A betegeket két alkalommal, a kiindulási és a 3 . hónapban értékelték, az 1. hónapban további opcionális vizit volt lehetséges. Beválasztáskor rögzítették a családi anamnézist és a beteg kórtörténetét, majd minden esetben fizikális vizsgálat történt. A rögzített kockázati tényezők a következők voltak: dohányzás, fizikai aktivitás, diabetes mellitus, magas vérnyomás, hypercholesterinaemia, korábbi myocardialis infarctus, megelőző ischaemiás stroke. A vérlemezkegátló, lipidcsökkentő, vérnyomáscsökkentő és antidiabetikus gyógyszereket szintén feljegyezték.

Az egészséggel összefüggő életminőséget (HQL) az EQ-5D-3L-kérdőívvel mértük, mely az egészségügyi állapot standardizált mérőszáma. A kérdőívet az EuroQol Csoport fejlesztette ki annak érdekében, hogy egyszerü, általános egészségügyi mérést biztosítson az életminőség klinikai és gazdasági értékeléséhez [20]. Az EQ-5D-3Lkérdőív magyar változata elérhető volt. Az EQ-5D-3L leíró rendszer a következő 5 dimenziót foglalja magában: mozgás, önellátás, szokásos tevékenységek, fájdalom/kellemetlenség és szorongás/depresszió. Minden dimenziónak 3 szintje van: nincs probléma (1), némi probléma (2), súlyos probléma (3). Az EQ-5D-3L alkalmazásával gyüjtött adatok különféle módon jeleníthetők meg. Az egyes egészségi állapotokat az egyes dimenziókban jelzett problémák szintje alapján azonosíthatjuk, melyet EQ-5D-profilnak nevezünk. Az EQ-5D leíró rendszer által definiált EQ-5D egészségi állapotokat egyetlen összegző indexszé alakíthatjuk egy olyan képlet alkalmazásával, amely lényegében értékeket (más néven 
súlyokat) csatol az egyes dimenziók minden szintjéhez. $\mathrm{Az}$ index kiszámítható úgy, hogy a megfelelő értékeket levonjuk az 1-ból, a teljes állapot értékéből (azaz az 11111 állapotból) [20].

Az alsó végtag funkcionális kapacitását a WELCH(Walking Estimated-Limitation Calculated by History) kérdőívvel értékeltük. Ennek használatához a kérdőív fejlesztője az írásos hozzájárulását adta [21]. Alkalmazása előtt Brislin visszafordítási módszerét alkalmaztuk az eszköz magyar változatának elkészítéséhez [22]. A WELCH-kérdőív a szokásos járásisebesség-elemet, valamint egy empirikus és nagyon egyszerú pontozási módszert használ, így értéke egyszerüen kiszámítható számítógép nélkül [23]. A WELCH négy kérdőíves elemet tartalmaz. Az első három kérdésben szereplő nyolc válasz mindegyikének értéke 0-tól 7-ig terjed, és az utolsó, a szokásos járási sebességgel foglalkozó elemre javasolt öt válasz mindegyikének koefficiense 1-től 5-ig terjed. Az 1-3. pontokra kapott értékek összege mínusz 1 (tehát 0 és 20 közötti érték, figyelembe véve, hogy minden beteg legalább 30 másodpercig képes járni a legkisebb sebességgel), szorozva az utolsó kérdés pontszámával.

1. táblázat |A viziteken végzett vizsgálatok

\begin{tabular}{|c|c|c|c|}
\hline Vizitek & Beválasztás & $\begin{array}{c}\text { Opcionális } \\
\text { vizit }\end{array}$ & $\begin{array}{l}\text { Záró } \\
\text { vizit }\end{array}$ \\
\hline A vizit időzítése & 1. nap & 1. hónap & 3. hónap \\
\hline A vizsgálat dátuma & $\mathrm{X}$ & $\mathrm{X}$ & $\mathrm{X}$ \\
\hline $\begin{array}{l}\text { Betegtájékoztató és beteg-bele- } \\
\text { egyező nyilatkozatok megléte }\end{array}$ & $\mathrm{X}$ & & \\
\hline $\begin{array}{l}\text { Beválasztási kritériumoknak való } \\
\text { megfelelés }\end{array}$ & $\mathrm{X}$ & & \\
\hline Demográfiai adatok & $\mathrm{X}$ & & \\
\hline Anamnesztikus adatok & $\mathrm{X}$ & & \\
\hline Életmód & $\mathrm{X}$ & & $\mathrm{X}$ \\
\hline Társbetegségek & $\mathrm{X}$ & & \\
\hline Rendelői vérnyomás és pulzus & $\mathrm{X}$ & $\mathrm{X}$ & $\mathrm{X}$ \\
\hline Boka-kar index & $\mathrm{X}$ & & $\mathrm{X}$ \\
\hline $\begin{array}{l}\text { A járástávolság rögzítése } \\
\text { (járópadlóteszt vagy } 6 \text { perces } \\
\text { járásteszt eredménye alapján) }\end{array}$ & $\mathrm{X}$ & & $\mathrm{X}$ \\
\hline EQ-5D-teszt & $\mathrm{X}$ & & $\mathrm{X}$ \\
\hline WELCH-teszt & $\mathrm{X}$ & & $\mathrm{X}$ \\
\hline $\begin{array}{l}\text { A beteg elégedettsége a } \\
\text { NOCLAUD }^{\circledR} \text {-terápiával } \\
(0-10 \text { pontos vizuális analóg } \\
\text { skála })\end{array}$ & & & $\mathrm{X}$ \\
\hline Aktuálisan szedett gyógyszerek & $\mathrm{X}$ & & $\mathrm{X}$ \\
\hline $\begin{array}{l}\text { Nemkívánatos események, } \\
\text { feltételezhető gyógyszermellék- } \\
\text { hatások, speciális szituációk }\end{array}$ & & $\mathrm{X}$ & $\mathrm{X}$ \\
\hline
\end{tabular}

EQ-5D = az egészségi állapotot értékelő kérdőív; WELCH = Walking Estimated-Limitation Calculated by History
A WELCH-kérdőívet hitelesítették a járópadlón mért járástávolsággal [21], valamint a 6 perces járásteszttel is [24] CI-ben. Ezekkel a nemzetközi eredményekkel öszszehangban a SHERIFF-vizsgálatban a WELCH-kérdőív és járópadteszt, valamint a 6 perces járásteszt eredményei között pozitív korrelációt találtunk. A korreláció (Spearman-féle) mértéke is a nemzetközi adatokhoz hasonlónak mutatkozott $[19,24]$. Mindezek alapján a kérdőív magyar populáció esetén történő használatát megalapozottnak láttuk.

A másodlagos célkitűzéseket, a fájdalommentes és a maximális járástávolságot, a BKI-t mindkét vizit során meghatározták. A fájdalommentes és a maximális járástávolságot standard járópadlóteszttel (0 fok emelkedés, $3,2 \mathrm{~km} / \mathrm{h}$ sebesség) vagy kijelölt útvonalon (20 vagy 30 m hosszú) mértük, a 6 perces járásteszthez hasonlóan (a beteg a saját tempójában járt), a vizsgálóhelyen elérhető módszertől függően [25]. A BKI-t a Doppler-módszerrel mért systolés nyomásból számítottuk. A betegeknek a CIL-terápiával való elégedettségét 0-10 pontos vizuális analóg skálán (VAS) értékelték a záró vizit során. A VAS pszichometrikus válaszskála, amely a szubjektív jellemzők vagy hozzáállás mérésére szolgál. A vizsgálatban ún. egytételes elégedettségskálát alkalmaztak: ezen a betegek az elégedettségüket 0 -10 pontos skálán értékelik, a végükön rögzített $10 \mathrm{~cm}$-es vonalon. A 0 azt jelenti, hogy teljesen elégedetlenek, a 10 pedig azt, hogy teljesen elégedettek. Az adverz eseményeket minden viziten rögzítették. A vizitek során végzett vizsgálatokat az 1 . táblázat tartalmazza.

\section{Statisztikai értékelés}

Az összegyújtött adatok analízisét az EU GCP/ICH szabványainak megfelelően független statisztikai centrum végezte. Általánosságban valamennyi - rendszerezetten gyưjtött - adat összesítésre került leíró statisztikai módszerekkel, a legtöbbször táblázatos formában. A vizsgálat hatásának értékelésekor az 'intention-to-treat' (kezelési szándék) elvet érvényesítettük, azaz arra kerestük a választ, hogy tudjuk a kezelés valós hatásait becsülni. A hatás szempontjából minden olyan beteget értékeltünk, aki aláírta a beteg-beleegyező nyilatkozatot, megfelelt a bevonási kritériumoknak, és nem sértett meg egyetlen bevonási feltételt sem. Az összehasonlító statisztikai elemzéssel a vizsgált paraméterek változása hatékonyan elvégezhető. A beválasztási, illetve záró vizit két hipotézisvizsgálatnak alávethető mintát szolgáltat: minden esetben arra keresünk választ, hogy az adott tulajdonság szignifikánsan változik, vagy a betegenkénti változás átlaga szignifikánsan eltér a nullától. A SHERIFFvizsgálat hipotéziseinek ellenőrzésére Wilcoxon-féle előjeles rangpróbát használtunk, amely a t-próba nemparametrikus megfelelője - ezt nem normális eloszlású változók esetén érdemes alkalmazni. Előnye még, hogy sokkal robusztusabb, mivel a t-próbához kevésbé hajlamos torzított eredményt mutatni az 'outlierek' (kiugró 
2. táblázat |A vizsgálatban részt vevő betegek jellemzői

\begin{tabular}{|c|c|c|c|c|}
\hline Jellemzők & $\begin{array}{c}\text { Összes } \\
\text { beteg } \\
(\mathrm{n}=812)\end{array}$ & $\begin{array}{c}\text { NDM } \\
(\mathrm{n}=482)^{*}\end{array}$ & $\begin{array}{c}\mathrm{DM} \\
(\mathrm{n}=318)^{*}\end{array}$ & $\mathrm{p}^{* *}$ \\
\hline Kor (év) & $\begin{array}{l}67,17 \pm \\
8,845\end{array}$ & $\begin{array}{c}66,56 \pm \\
8,786\end{array}$ & $\begin{array}{l}68,17 \pm \\
8,791\end{array}$ & $<0,05$ \\
\hline Férfi/nő (\%) & $\begin{array}{l}58,25 / \\
41,75\end{array}$ & $\begin{array}{r}59,54 / \\
40,46\end{array}$ & $\begin{array}{c}56,6 / \\
43,4\end{array}$ & $\begin{array}{l}\text { NS/ } \\
\text { NS }\end{array}$ \\
\hline Dohányzás jelenleg (\%) & 33,25 & 38,38 & 25,79 & $<0,05$ \\
\hline $\begin{array}{l}\text { Dohányzás a kórelőz- } \\
\text { ményben }(\%)\end{array}$ & 29,68 & 28,22 & 32,08 & NS \\
\hline Hypertonia (\%) & 82,14 & 78,01 & 88,68 & $<0,05$ \\
\hline Dyslipidaemia (\%) & 57,27 & 46,27 & 74,53 & $<0,05$ \\
\hline Agyérbetegség (\%) & 13,55 & 11,62 & 16,67 & $<0,05$ \\
\hline Korábbi AMI (\%) & 5,91 & 4,56 & 7,86 & NS \\
\hline PAD a családban (\%) & 36,45 & 35,27 & 37,11 & NS \\
\hline Vesebetegség (\%) & 6,4 & 2,49 & 12,26 & $<0,05$ \\
\hline $\begin{array}{l}\text { Fizikai aktivitás (\%) } \\
\text { könnyű } \\
\text { 1-2/hét } \\
\text { >3/hét }\end{array}$ & $\begin{array}{r}62,0 \\
14,1 \\
7,2\end{array}$ & $\begin{array}{r}61,0 \\
16,6 \\
7,7\end{array}$ & $\begin{array}{r}63,52 \\
11,01 \\
6,92\end{array}$ & $\begin{array}{c}\text { NS } \\
<0,05 \\
\text { NS }\end{array}$ \\
\hline $\begin{array}{l}\text { Vérlemezkegátló } \\
\text { kezelés }(\%)\end{array}$ & 69,98 & 58,71 & 78,61 & $<0,05$ \\
\hline $\begin{array}{l}\text { Lipidcsökkentő kezelés } \\
(\%)\end{array}$ & 66,88 & 54,78 & 85,22 & $<0,05$ \\
\hline $\begin{array}{l}\text { ACE-gátló/ARB } \\
\text { kezelés (\%) }\end{array}$ & 71,43 & 65,35 & 81,5 & $<0,05$ \\
\hline
\end{tabular}

* 12 beteg esetében hiányzott az információ a diabetesre vonatkozó an, adataik csak az 'összes beteg' csoportban kerültek értékelésre;

** $\mathrm{p}$ a diabeteses (DM) csoport a nem diabeteses (NDM) csoporthoz képest; ha $<0,05$, akkor szignifikáns a különbség, ha $\geq 0,05$, akkor nincs különbség (NS).

ACE = angiotenzin-konvertáló enzim; AMI = akut myocardialis infarctus; $\mathrm{ARB}=$ angiotenzin-II-receptor-blokkoló; $\mathrm{DM}=$ diabeteses; NDM = nem diabeteses; $\mathrm{PAD}=$ perifériás verőérbetegség

értékek) miatt (ha a mintánk tartalmaz egy olyan adatpontot, amely messze van az átlagtól - távolabb, mint kétszórásnyira -, akkor az ronthatja a t-próba eredményeit). A Wilcoxon-féle előjeles rangpróbával az egyik esetben (kétmintás változat) azt a nullhipotézist ellenöriztük, miszerint a két minta ugyanabból a populációból származik, vagy (egymintás esetben) az adott paraméter változása zérus. A statisztikai következtetésben azt a változást tekintettük szignifikánsnak, amelynél az adott próba p-értéke kisebb, mint 0,0001. A nullhipotézis elvetése értelemszerúen a terápia hatásosságát bizonyítja.

\section{Eredmények}

A teljes populáció, illetve a DM- és NDM-betegcsoportok alapadatait és jellemzőit a 2. táblázat mutatja. Az egészséggel kapcsolatos életminőség 3 hónapos CIL-kezelés után javult, ez megfigyelhető volt az EQ-5D-kérdőív minden dimenziójában (3. táblázat), és ezt az
3. táblázat $\mid$ Az EQ-5D-kérdő́ivben problémát jelzők aránya a beválasztás kor és a 3. hónapos viziten

\begin{tabular}{lcc}
\hline EQ-5D-dimenziók & Beválasztás & 3. hónap \\
\hline Mozgékonyság & & \\
Nincs probléma & $5,0 \%$ & $31,3 \%$ \\
Némi probléma & $92,2 \%$ & $66,13 \%$ \\
Súlyos probléma & $1,7 \%$ & $0,37 \%$ \\
\hline Önellátás & & \\
Nincs probléma & $52,8 \%$ & $75,7 \%$ \\
Némi probléma & $44,46 \%$ & $21,31 \%$ \\
Súlyos probléma & $2,22 \%$ & $0,37 \%$ \\
\hline Szokásos tevékenységek & & \\
Nincs probléma & $34,1 \%$ & $62,6 \%$ \\
Némi probléma & $58,13 \%$ & $34,11 \%$ \\
Súlyos probléma & $6,90 \%$ & $1,23 \%$ \\
\hline Fájdalom/rossz közérzet & & \\
Nincs probléma & $15,2 \%$ & $53,3 \%$ \\
Némi probléma & $69,0 \%$ & $43,72 \%$ \\
Súlyos probléma & $14,8 \%$ & $0,74 \%$ \\
\hline Szorongás/lehangoltság & & \\
Nincs probléma & $41,3 \%$ & $63,72 \%$ \\
Némi probléma & $45,3 \%$ & \\
Súlyos probléma & $8,4 \%$ & \\
\hline
\end{tabular}

EQ-5D = az egészségi állapotot értékelő kérdőív

EQ-5D-index változása is bizonyította (kiindulási érték: összes beteg $-0,46 \pm 0,22, \mathrm{NDM}-0,45 \pm 0,22, \mathrm{DM}$ $-0,48 \pm 0,23,3$. hónap: összes beteg $-0,26 \pm 0,18$, $\mathrm{NDM}-0,24 \pm 0,18, \mathrm{DM}-0,27 \pm 0,19 ; \mathrm{p}<0,0001)$ (1. ábra). A WELCH-pontszám változása megerősítette az alsó végtag funkcionális kapacitásának jelentős javulását (kiindulási érték: összes beteg $19 \pm 14$, NDM $20 \pm$ 14, DM $18 \pm 14 ; 3$. hónap: összes beteg $31 \pm 18, \mathrm{NDM}$ $33 \pm 19$, DM $29 \pm 16 ; \mathrm{p}<0,0001$ ) (2. ábra). A járástávolságot $136(16,7 \%)$ beteg esetében járópadlón, egyébként a beteg saját járástempójában mértük. Mind a fájdalommentes, mind a maximális járástávolság szignifikánsan javult: összes beteg 54,52\% (medián: $53,85 \%$ ) és 42,5\% (medián: 34,68\%); NDM 59,2\% (medián: 50,0\%), 46,58 (medián: 40,51\%); és DM 42,85\% (medián: 43,33\%), 41,61\% (medián: 34,68\%); ( $\mathrm{p}<0,001)$, az abszolút értékeket a 3. ábra mutatja. 3 hónapos CIL-kezelés után a BKI 0,73 \pm 0,16-ról 0,79 $\pm 0,15$-re nőtt $(\mathrm{p}<0,0001)$, a NDM- és a DM-csoport között nem volt különbség. A CIL-kezeléssel való elégedettségre vonatkozó 0-10 pontos VAS a záró vizit során az elégedettség nagy előfordulását mutatta, az 1-4 közötti értékeket az alanyok kevesebb mint 2\%-a választotta (4. ábra).

\section{Megbeszélés}

Vizsgálatunk több mint 800, CI-ben szenvedő beteg megfigyelése során alátámasztotta, hogy a 3 hónapos CIL-kezelés javítja az életminőséget és az alsó végtagi funkcionális kapacitást; a javulás DM- és NDM-betegekben egyaránt kimutatható volt. 

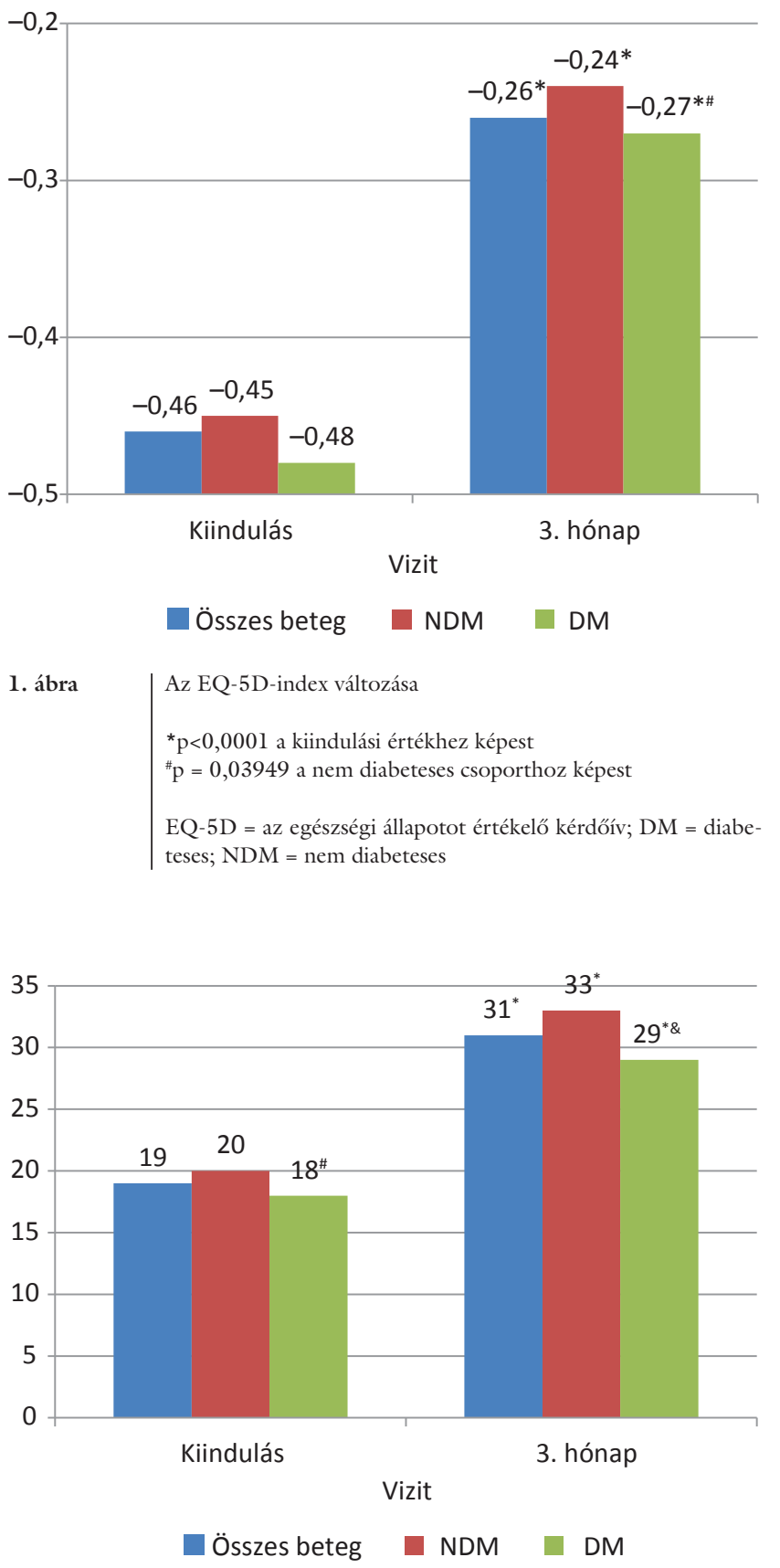

\begin{tabular}{l|l} 
2. ábra & $\begin{array}{l}\text { A WELCH-pontérték változása } \\
{ }^{*} \mathrm{p}<0,0001 \text { a kiindulási értékhez képest } \\
{ }^{\#} \mathrm{p}=0,00475 \text { a nem diabeteses csoporthoz képest } \\
{ }^{8} \mathrm{p}=0,03348 \text { a nem diabeteses csoporthoz képest }\end{array}$ \\
& $\begin{array}{l}\mathrm{DM}=\text { diabeteses; } \mathrm{NDM}=\text { nem diabeteses; WELCH }=\text { Walking } \\
\text { Estimated-Limitation Calculated by History }\end{array}$
\end{tabular}

A fájdalommentes és a maximális járástávolságot standard járópadlóteszttel vagy kijelölt útvonalon megfigyelt járással mértük. A 3 hónapos CIL-kezelés után szignifikáns javulást tapasztaltunk ezekben a fizikai paraméterekben, és a hatás nagysága jó összhangban volt a korábbi publikációk eredményeivel [15]. Hasonlóképpen, a BKI-nek a vizsgálatunkban megfigyelt mérsékelt növekedése összhangban volt más közlemények adataival, mind

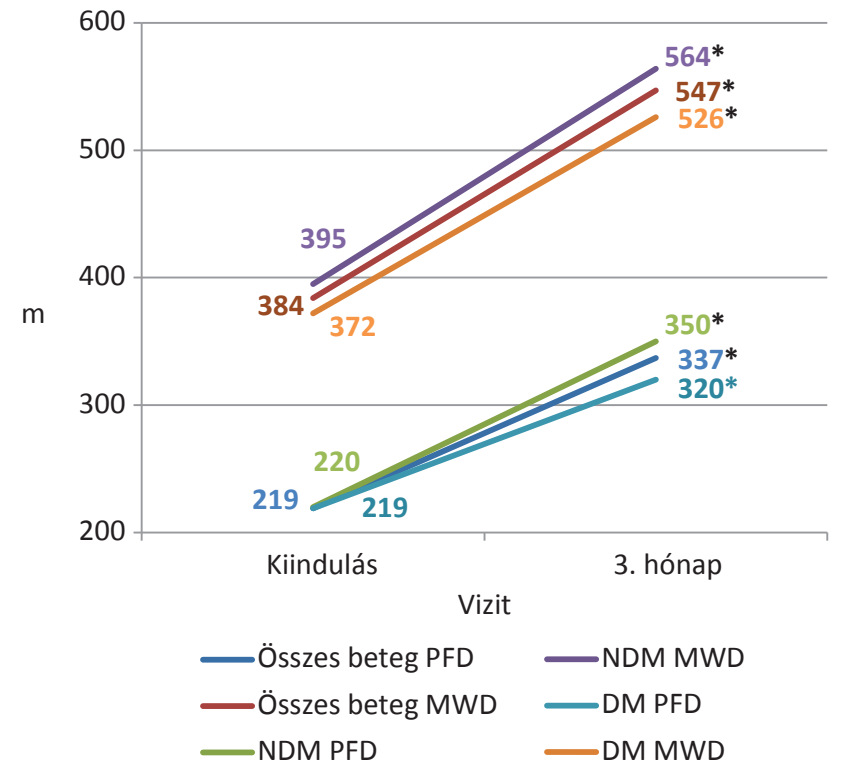

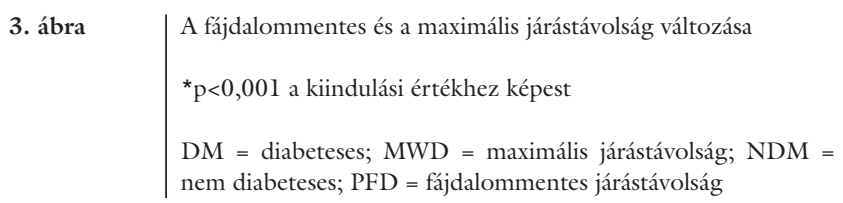

$0,37 \%$

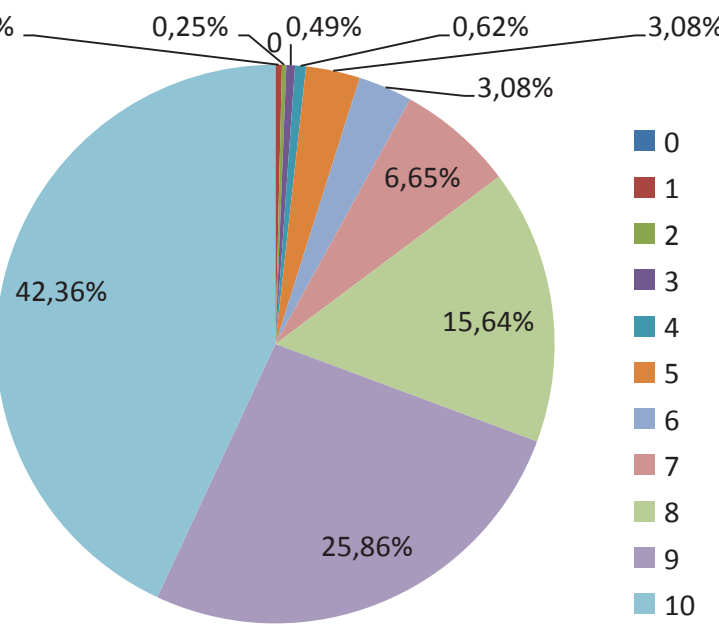

\begin{tabular}{l|l} 
4. ábra & $\begin{array}{l}\text { Betegelégedettség a záró viziten vizuális analóg skálával mérve } \\
\text { A betegek } 0-10 \text {-ig terjedő skálán jelölték az elégedettségüket a } \\
\text { terápiával kapcsolatban, a } 0 \text { jelenti a teljes elégedetlenséget, a } 10 \\
\text { pedig a teljes elégedettséget }\end{array}$
\end{tabular}

a növekedés tényének, mind a változás mértékének tekintetében [15]. A CIL-kezelés egyik fontos szempontja, hogy nemkívánatos események csak 10 betegnél fordultak elő, a kezelés felfüggesztésére mindössze 1 beteg esetében került sor. Ezek az eredmények a korábbi tanulmányok következetes reprodukciójának tekinthetók [14], és megegyeznek a NOCLAUD-vizsgálat korábbi tapasztalataival is [18]. A CIL-kezelés kiemelkedő hatékonyságát és jó tolerálhatóságát a betegeknek a VAS alapján mért elégedettsége is igazolta. 
A SHERIFF-vizsgálatban Magyarországon először alkalmaztunk PROM-alapú értékelést a CI CIL-kezelése során [19]. A korábbi tanulmányokkal ellentétben az EQ-5D-3L használatát választottuk a HQL becslésére, és a WELCH-tesztet, amely PAD-specifikus eszköz az alsó végtagi funkcionális kapacitás mérésére. Ez utóbbi viszonylag új lehetőség a klinikai gyakorlatban [22]. A HQL jelentős romlása PAD-betegekben ismert [26]. Korábbi multicentrikus tanulmányunkban az EQ-5D-3Lkérdőívvel mért HQL-romlás arányos volt a Fontainestádiumokkal jellemzett PAD súlyosságával [27]. Ebben a tanulmányban a maximális járástávolság és az alsó végtagi fájdalom mutatta a legerôsebb korrelációt az EQ-5D-index értékével. Több multicentrikus vizsgálatban kimutatták a HQL javulását különböző revascularisatiós beavatkozásokat követően [28, 29], és a 6 hónapos ellenőrzött tréningprogramnak a HQL-re gyakorolt jótékony hatását egy Cochrane-metaanalízis is megerősítette [30]. Obszervációs vizsgálatunkban az EQ-5D-3Lkérdőív felhasználásával a mindennapi klinikai gyakorlatban több mint 800 PAD-betegben (318 DM) meg tudtuk mérni a HQL-t. A jelentős javulást a kérdőív minden dimenziójában megfigyeltük. A járóképesség romlása és a végtagfájdalom hatással van az egészségi állapot más dimenzióira is, például az önellátásra, a szokásos tevékenységekre és a szorongásra/depresszióra. A kezelés jótékony hatását statisztikailag igazoltuk az EQ-5D-index változásával. Az EQ-5D-indexben észlelt különbséget magyarázza az a tény, hogy a DM-betegcsoport idősebb volt, nagyobb volt a hypertoniának, a dyslipidaemiának és a krónikus vesebetegségnek az előfordulása, ugyanakkor a nagyobb kockázatnak megfelelően a betegek nagyobb arányban részesültek vérlemezkegátló, lipidcsökkentő és RAS-gátló terápiában. Az EQ-5Dindex javulásának mértéke nem különbözött a DM- és a NDM-csoportban. A CIL az értágító és vérlemezkegátló hatása révén javítja a járóképességet és csökkenti a végtagi fájdalmat; az önellátás javulása segíti a betegeket a szokásos tevékenységek elvégzésében, és csökkenti a szorongást - mindezen hatások az életminőség javulását eredményezik.

A közelmúltban megalkotott WELCH-kérdőívet nemrégiben javasolták új, egyszerü és könnyen alkalmazható eszközként a CI-ben szenvedő betegek járóképességének felmérésére. A WELCH-kérdőívet már több nyelven validálták [23, 31], Magyarországon a SHERIFFvizsgálatban alkalmaztuk először [19]. A WELCH-pontszám a 3 hónapos CIL-kezelést követően szignifikánsan nőtt, az eredmény szignifikáns korrelációt mutatott a mért járástávolságokkal - az erre vonatkozó részletes adatokat illetően utalunk a vizsgálat korábbi publikációjára [31]. A WELCH-kérdőív alapján mért járóképesség - a DM-betegcsoportot jellemző, korábban említett tényezők miatt - a DM-betegekben kisebb volt. A WELCH-kérdőívvel mért javulás mértéke szintén nem különbözött a DM- és NDM-betegekben. Eredményeink azt mutatják, hogy a CIL-kezelés hatása a járóképes- ségre egyszerúen kiértékelhető a WELCH-kérdőív segítségével a klinikai gyakorlatban, ahol a járástávolság mérése gyakran akadályokba ütközik.

A diabetes a PAD jól ismert rizikótényezője, ugyanakkor cukorbetegekben az érszúkület felismerése gyakran nehézségekbe ütközik. Dolan és mtsai 460 PAD-beteg (147 DM) vizsgálatakor azt állapították meg, hogy DM-betegekben a klasszikus CI tünetei ritkábban fordultak elő, kisebb volt a 6 perces járásteszt során megtett távolság, és alacsonyabb volt a járási sebesség [32]. Egy 1192 (920 értékelhető, 477 DM) PAD-beteg bevonásával végzett prospektív, obszervációs vizsgálatban az EQ-5D-5L-kérdőívvel értékelték az életminőséget és a WIQ-kérdőívvel a betegek járóképességét [33]. A DMbetegekben nagyobb volt a hypertoniának és más cardiovascularis rizikótényezőknek az előfordulása. A WIQkérdőívvel mért járóképesség és a HQL is szignifikánsan rosszabb volt DM-betegekben a NDM PAD-betegekhez képest. Vizsgálatunkban a korábbi publikációkhoz hasonlóan [32, 33] kismértékü, de statisztikailag szignifikáns különbséget találtunk az EQ-5D-index és a WELCH-pontszám tekintetében is a NDM-betegekhez képest, ugyanakkor a CIL-kezelés során mért javulás mértéke azonos volt a DM- és a NDM-csoportban. Eredményeink megerősítik a DM-betegekben kialakuló PAD korai felismerésének jelentőségét, amiben az egyszerüen használható WELCH-kérdőív is segítséget nyújthat a mindennapi klinikai gyakorlatban, mivel a fájdalom jelenléte nélkül is, a járási sebesség alapján igazolhatja a járóképesség romlását. Az időben megkezdett szisztémás prevenciós kezelés és az alsó végtagi artériás keringés javítása csökkentheti a súlyosabb stádiumoknak, a kritikus végtagischaemia kialakulásának kockázatát [34].

\section{Következtetés}

A jelen vizsgálat célja az életminőség és a funkcionális kapacitás vizsgálata volt CI-ben szenvedő DM- és NDMbetegekben. A 3 hónapos CIL-kezelés szignifikánsan javította az EQ-5D-3L-kérdőívvel mért életminőséget és az alsó végtagi funkcionális kapacitást, a javulás mértéke azonos volt diabetes esetén is. A kezelés során a mellékhatások előfordulása ritkán korlátozta a szer alkalmazását, súlyos mellékhatás, vérzés nem volt. A claudicatio kezelése során a WELCH-kérdőív hasznos eszköznek bizonyult a klinikai gyakorlatban a járóképesség értékelésére. Vizsgálatunk a jövőben hozzájárulhat a WELCHkérdőív használatának magyarországi elterjedéséhez, és ezáltal segítheti a PAD korai felismerését DM-betegekben is.

\section{Korlátok}

Tanulmányunk nem randomizált vizsgálat volt, hanem 100 központban szerzett, „való világ” adatokon alapuló obszervációs vizsgálat. A DM- és NDM-betegek alap- 
adatai több tényezőben is különbséget mutattak, amelyek befolyásolhatták a kapott eredményeket. Az egymást követő betegeknek a vizsgálatba történő beválasztása nem tette szükségessé olyan alanyok dokumentálását, akik nem adták beleegyezésüket a részvételhez. Ugyanakkor a különböző központokban toborzott betegek száma kiegyensúlyozott volt, ennek alapján nem feltételezhetó, hogy egy adott központ hatása szignifikáns. Mindazonáltal nem zárható ki a szelekció bizonyos fokú torzulása.

Anyagi támogatás: A vizsgálat az Egis Gyógyszergyár Zrt. anyagi támogatásával valósult meg.

Szerzői munkamegosztás: F. K.: A vizsgálati protokoll kidolgozása, a kézirat megszövegezése. K. E.: A statisztikai elemzések értékelése, a kézirat megszövegezése. J. Z.: A kézirat megszövegezése. A közlemény végleges változatát valamennyi szerző elolvasta és jóváhagyta.

Érdekeltségek: A szerző́knek nincsenek érdekeltségeik.

\section{Köszönetnyilvánítás}

Köszönetet mondunk a statisztikai munkáért Jánosi Istvánnak és Párkányi Dénesnek.

Köszönet illeti a SHERIFF-vizsgálatban részt vett szakorvosokat: Ambrusics Anna, Asefa Abebe, Bakonyi Géza, Balogh Gábor, Barta László, Benedek Zsolt, Benkö László, Bognár János, Botos Aranka, Brasnyó Pál, Cserényi László, Cseri István, Dobai Attila, Farkas Klára, Füzi Árpád, Gál István, Gáll András, Gellért Gábor, Giesecke Annamária, Gombos Zita, Gödri Imola, Guba László Áron, Hamza Eszter, Hajdú László, Hájer Gyula, István Miklós, Jakab Lajos, Jancsó Gábor, Kabáczy Miklós, Kecskés István, Király László, Kiséry Csaba, Kiss Julianna, Kiszely Ildikó, Kocsi Anikó, Kocsis Ildikó, Kozlovszky Bertalan, Kovács László Roland, Kósa Éva, Krasznai Attila, Kun Éva, Lovas László, Luthár András, Marton Éva, Mátyus Áron, Ménesi Rudolf, Mikola József, Mogyorósi József, Mousbeh Yousef, Murányi Anikó, Nagy András, Nagy Árpád, Nagy György, Németh Ákos, Németh József, Nouri Salam, Oroszlán Zsolt, Paizer Ildikó, Páll Istvám, Pál Zsuzsa, Pusztai Ferenc, Raskó Endre, Rémán Gyöngyvér Éva, Rokszin Tibor, Sabin-Tóth Gábor, Sarkadi László, Sebö Nóra, Szabó Géza, Szakács Piroska Veronika, Szentesi Szabolcs, Széll András, Szi Vince, Takács Emerencia, Takács Tibor, Teknös Dániel, Tidir Antal, Únyi Zsuzsanna, Varga Eszter, Vass Andrea, Vértes András, Végh Edith, Végh Tibor, Vidróczki Erzsébet, Vizsy László, Zöld Attila.

\section{Irodalom}

[1] Criqui MH, Fronek A, Barrett-Connor E, et al. The prevalence of peripheral arterial disease in a defined population. Circulation 1985; 71: 510-515

[2] Fowkes FG, Rudan D, Rudan I, et al. Comparison of global estimates of prevalence and risk factors for peripheral artery disease in 2000 and 2010: a systematic review and analysis. Lancet 2013; 382: 1329-1340.

[3] Selvin E, Erlinger TP. Prevalence of and risk factors for peripheral arterial disease in the United States: results from the $\mathrm{Na}$ tional Health and Nutrition Examination Survey, 1999-2000. Circulation 2004; 110: 738-743.
[4] Sigvant B, Wiberg-Hedman K, Bergqvist D, et al. A populationbased study of peripheral arterial disease prevalence with special focus on critical limb ischemia and sex differences. J Vasc Surg. 2007; 45: 1185-1191.

[5] Thiruvoipati T, Kielhorn CE, Armstrong EJ. Peripheral artery disease in patients with diabetes: epidemiology, mechanisms, and outcomes. World J Diabetes 2015; 10: 961-969.

[6] Diehm C, Lange S, Darius H, et al. Association of low ankle brachial index with high mortality in primary care. Eur Heart J. 2006; 27: 1743-1749.

[7] Wild SH, Byrne CD, Smith FB, et al. Low ankle-brachial pressure index predicts increased risk of cardiovascular disease independent of the metabolic syndrome and conventional cardiovascular risk factors in the Edinburgh Artery Study. Diabetes Care 2006; 29: 637-642.

[8] Lamina C, Meisinger C, Heid IM, et al., for the KORA Study Group. Association of ankle-brachial index and plaques in the carotid and femoral arteries with cardiovascular events and total mortality in a population-based study with 13 years of follow-up. Eur Heart J. 2006; 27: 2580-2587.

[9] Regensteiner JG, Hiatt WR, Coll JR, et al. The impact of peripheral arterial disease on health-related quality of life in the Peripheral Arterial Disease Awareness, Risk, and Treatment: New Resources for Survival (PARTNERS) Program. Vasc Med. 2008; 13: 15-24.

[10] Breek JC, Hamming JF, De Vries J, et al. The impact of walking impairment, cardiovascular risk factors, and comorbidity on quality of life in patients with intermittent claudication. J Vasc Surg. 2002; 36: 94-99.

[11] Gardner AW, Montgomery PS, Wang M, et al. Predictors of health-related quality of life in patients with symptomatic peripheral artery disease. J Vasc Surg. 2018; 68: 1126-1134.

[12] Conijn AP, Jens S, Terwee CB, et al. Assessing the quality of available patient reported outcome measures for intermittent claudication: a systematic review using the COSMIN checklist. Eur J Vasc Endovasc Surg. 2015; 49: 316-334.

[13] McDermott MM. Functional impairment in peripheral artery disease and how to improve it in 2013. Curr Cardiol Rep. 2013; 15: 347 .

[14] Gerhard-Herman MD, Gornik HL, Barrett C, et al. 2016 AHA/ ACC Guideline on the management of patients with lower extremity peripheral artery disease: a report of the American College of Cardiology/American Heart Association Task Force on Clinical Practice Guidelines. Circulation 2017; 135: e726-e779. [Correction: Circulation 2017; 135: e791-e792.]

[15] Bedenis R, Stewart M, Cleanthis M, et al. Cilostazol for intermittent claudication. Cochrane Database Syst Rev. 2014; 2014: CD003748.

[16] Regensteiner JG, Ware JE Jr, McCarthy WJ, et al. Effect of cilostazol on treadmill walking, community-based walking ability, and health-related quality of life in patients with intermittent claudication due to peripheral arterial disease: meta-analysis of six randomized controlled trials. J Am Geriatr Soc. 2002; 50: 1939-1946.

[17] Thompson PD, Zimet R, Forbes WP, et al. Meta-analysis of results from eight randomized, placebo-controlled trials on the effect of cilostazol on patients with intermittent claudication. Am J Cardiol. 2002; 90: 1314-1319.

[18] Farkas K, Járai Z, Kolossváry E. Cilostazol is effective and safe option for the treatment of intermittent claudication. Results of the NOCLAUD study. [A cilostazol hatékony és biztonságos lehetőség a claudicatio intermittens kezelésére. A NOCLAUD vizsgálat eredményei.] Orv Hetil. 2017; 158: 123-128. [Hungarian]

[19] Farkas K, Kolossváry E, Járai Z. Simple assessment of quality of life and lower limb functional capacity during cilostazol treatment - results of the SHort-tERm cIlostazol eFFicacy and quality of life (SHERIFF) study. Vasa 2020; 49: 235-242. 
[20] EuroQol Group. EuroQol - a new facility for the measurement of health-related quality of life. Health Policy 1990; 16: 199_ 208.

[21] Abraham P, Godet R, Harbonnier M, et al. External validation of the "Walking Estimated Limitation Calculated by History" (WELCH) questionnaire in patients with claudication. Eur J Vasc Endovasc Surg. 2014; 47: 319-325.

[22] Brislin RW. Back-translation for cross-cultural research. J Cross Cult Psychol. 1970; 1: 187-216.

[23] Ouedraogo N, Chanut M, Aubourg M, et al. Development and evaluation of the Walking Estimated-Limitation Calculated by History questionnaire in patients with claudication. J Vasc Surg. 2013; 58: 981-988

[24] Tew GA, Nawaz S, Humphreys L, et al. Validation of the English version of the Walking Estimated-Limitation Calculated by History (WELCH) questionnaire in patients with intermittent claudication. Vasc Med. 2014; 19: 27-32.

[25] Hiatt WR, Rogers RK, Brass EP. The treadmill is a better functional test than the 6-minute walk test in therapeutic trials of patients with peripheral artery disease. Circulation 2014; 130: 69-78.

[26] Harwood AE, Totty JP, Broadbent E, et al. Quality of life in patients with intermittent claudication. Gefässchirurgie 2017; 22: 159-164.

[27] Balogh O, Péntek M, Gulácsi L, et al. Quality of life and burden of disease in peripheral arterial disease: a study among Hungarian patients. [Magyarországi perifériás verőérbetegek életminőség és betegségteher vizsgálatának eredményei.] Orv Hetil. 2013; 154: 464-470. [Hungarian]
[28] Devine EB, Alfonso-Cristancho R, Yanez ND, et al., for the Comparative Effectiveness Research Translation Network (CERTAIN) Collaborative. Effectiveness of a medical vs revascularization intervention for intermittent leg claudication based on patient-reported outcomes. JAMA Surg. 2016; 151: el62024.

[29] Rastan A, McKinsey JF, Garcia LA, et al. One-year outcomes following directional atherectomy of popliteal artery lesions: subgroup analysis of the prospective, multicenter DEFINITIVE LE trial. J Endovasc Ther. 2018; 25: 100-108.

[30] Lane R, Harwood A, Watson L, et al. Exercise for intermittent claudication. Cochrane Database Syst Rev. 2017; 12: CD000990.

[31] Cucato GG, de Almeida Correia A, Farah BQ, et al. Validation of a Brazilian Portuguese version of the Walking Estimated-Limitation Calculated by History (WELCH). Arq Bras Cardiol. 2016; 106: 49-55.

[32] Dolan NC, Liu K, Criqui MH, et al. Peripheral artery disease, diabetes, and reduced lower extremity functioning. Diabetes Care 2002; 25: 113-120.

[33] Lozano FS, González-Porras JR, March JR, et al. Diabetes mellitus and intermittent claudication: a cross-sectional study of 920 claudicants. Diabetol Metab Syndr. 2014; 6: 21.

[34] Nativel M, Potier L, Alexandre L, et al. Lower extremity arterial disease in patients with diabetes: a contemporary narrative review. Cardiovasc Diabetol. 2018; 17: 138

(Farkas Katalin dr., Budapest, Tétényi út 12-16., 1115 e-mail: farkask@hotmail.com)

\section{A rendezvények és kongresszusok híranyagának leadása}

a lap megjelenése előtt legalább 40 nappal lehetséges, a 6 hetes nyomdai átfutás miatt. Kérjük megrendelőink szíves megértését.

A híranyagokat a következő címre kérjük: Orvosi Hetilap titkársága: edit.budai@akademiai.hu Akadémiai Kiadó Zrt.

A cikk a Creative Commons Attribution 4.0 International License (https://creativecommons.org/licenses/by/4.0/) feltételei szerint publikált Open Access közlemény, melynek szellemében a cikk bármilyen médiumban szabadon felhasználható, megosztható és újraközölhetö, feltéve, hogy az eredeti szerző és a közlés helye, illetve a CC License linkje és az esetlegesen végrehajtott módosítások feltüntetésre kerülnek. (SID_1) 